bustion-ignition engine to maintain it in efficient service is again paralleled by the development of replaceable sprayers, which, however, have to solve the more difficult problem of replacement without shutting down the main plant.

In the aerodynamics laboratory was an interesting single-stage air turbine. The laboratory already has substantial facilities for aerodynamic work, particularly on turbine blading; but these are to be extended still further when the high-speed variable-density cascade tunnel, which has been designed to enable independent control of the Mach and Reynolds numbers, is installed.

A considerable amount of development in measurement of noise was evidenced by the equipment on view both in the applied science and in the small mechanical laboratories. Those who have experienced the unpleasant sensations which can be associated with the noise from a blower will be grateful for the development of acoustic filters which, although simple in design, were shown to reduce an almost intolerable noise to within the limits of comparative comfort.

The work at the Research Station has led to the development of a very considerable amount of ingenious and effective measuring equipment. Particular reference should perhaps be made to the wave analyser which is now being marketed commercially in the name of 'Muirhead-Pametrada'. The progress in dealing with the problem of noise and vibrations generally is striking.

The strides that have been made by the Association in the eight years since its foundation reflect immense credit on it and its staff, particularly the research director, Dr. T. W. F. Brown. One of the most important factors contributing to its achievement must undoubtedly be that the Station is closely associated with the commercial success of its designs, so that although the work is frequently of a fundamental nature or indeed concerned with the development of equipment to measure the variables in a fundamental investigation, there is in the last event the acid test of whether the designs will work in a ship's installation to keep the feet of the staff firmly on the ground. During the six years since the first turbine designed at the Station went into service, more than fifty sets have been installed and are in satisfactory operation.

\section{GEORGE E. DAVIS (1850-1907) AND CHEMICAL ENGINEERING}

A MEETING was held in Manchester on October A 10, under the auspices of the Institution of Chemical Engineers and the Society of Chemical Industry, to commemorate George E. Davis, who is recognized throughout the English-speaking world as the pioneer of chemical engineering. The principal feature of the meeting was a Memorial Lecture given at the College of Technology by Mr. Norman Swindin, who was closely associated with Davis during $1900-7$.

George Edward Davis was born at Eton in 1850 and studied chemistry at the Slough Mechanics Institute and the Royal School of Mines, London. After a period spent in obtaining industrial experience in a variety of chemical works, Davis set up in private practice, as what would now be called a consulting chemical engineer, in Manchester in 1880. Very soon after this, however, he became an alkali inspector and did not return to his private practice until 1884 . The remaining twenty-three years of his life he devoted mainly to his practice and to editing The Chemical Trade Journal, which he founded in 1887 and which still flourishes.

Davis made major contributions to two important industrial processes. His first love was the gas industry, and when he was only eighteen he began research on the extraction of benzene from coal gas ; this side of his work culminated in the erection of a by-product plant at Rockingham which was technically ahead of its time and was not superseded until after his death. He also made great contributions to the Leblanc soda process and the allied Weldon process for the manufacture of chlorine. He himself devised a process for the production of chlorine by the oxidation of hydrochloric acid by nitric acid; this was not a commercial success, largely for the same reasons, technical and economic, which were leading at this time to the rapid decline of the once all-important Leblanc process. In all his work, doubtless owing to his experience as an alkali inspector, Davis scrupulously avoided waste and its accompanying nuisances of smoke, noxious fumes and river pollution.

His wide industrial experience brought home to Davis the fact that many promising laboratory processes failed to come to industrial fruition, not because of any chemical defects, but solely owing to the lack of men possessing the skill and knowledge necessary for the erection of adequate plant. The lack of such persons "possessing a knowledge of chemistry, physics and mechanics and who employed their knowledge for the utilization of chemical reactions on the large scale" he strove to set right by delivering, in 1887, a course of lectures on chemical engineering (the first lectures in the world on the subject) at the old Manchester Technical School, now the Manchester College of Technology ; he collected these lectures together, in an expanded form, in his two-volume "Handbook of ChemicaI Engineering", which was published in Manchester in 1901 and was the first text-book on this subject. The seed which Davis sowed in 1887 has flourished, and the vital importance of chemical engineering is now universally recognized.

Mr. Norman Swindin's excellent Memorial Lecture will be published by the Institution of Chemical Engineers and should, and no doubt will, be read by every chemical engineer and student of chemical engineering. Something more than this, however, seems necessary as a memorial to a man who, it is increasingly being realized, was one of the true pioneers of the modern world. In his lecture $\mathrm{Mr}$. Swindin said that Davis strongly advocated the foundation of chairs of chemical engineering and held that the Manchester College of Technology was the ideal training-ground for industrial chemists of all kinds ; the College, for its part, has always insisted on adequate engineering training for all its chemical students and was the first in England to institute a bachelor's degree in chemical engineering. Chemical industry throughout the world owes much to Davis ; it could find no better way of recognizing, and in part repaying, this debt than by adequately endowing, as a memorial to him, the school of chemical engineering in the institution in which he founded the subject and which he admired so much.

H. N. RYDoN 